\title{
HUBUNGAN PERAN BIDAN PADA PELAKSANAAN INISIASI MENYUSUI DINI (IMD) DALAM PERSALINAN DENGAN PROGRAM IMD PADA IBU BERSALIN DI RUMAH SAKIT WILAYAH KOTA PEKALONGAN
}

\author{
Diah Atmarina Yuliani \\ Prodi Kebidanan D III, Universitas Muhammadiyah Purwokerto, yuliani_da@yahoo.com
}

\begin{abstract}
ABSTRAK
Inisiasi menyusu dini (IMD) sangat penting bagi ibu dan bayi. Bayi disusui selama 1 jam atau lebih di dada ibu sesegera setelah lahir. Pelaksanaan IMD pada ibu bersalin membutuhkan peran penting bidan, namun program IMD belum berjalan sesuai yang diharapkan. Penelitian ini bertujuan untuk mengetahui hubungan peran bidan pada pelaksanaan Inisiasi Menyusu Dini (IMD) dalam Persalinan dengan program IMD pada ibu bersalin di Rumah Sakit Wilayah Kota Pekalongan. Desain penelitian mengunakan deskriptif korelatif dengan pendekatan cross sectional. Sampel penelitian bidan di Rumah Sakit Wilayah Kota Pekalongan sebanyak 53 orang. Teknik pengambilan sampel mengunakan total sampling. Pengumpulan data menggunakan kuesioner dan observasi. Hasil analisa univariat diketahui peran bidan dalam pelaksanaan IMD sebagian besar cukup yaitu 31 orang (58,3\%). Program IMD pada ibu bersalin sebagian besar yaitu 37 orang (69,8\%) tidak dilaksanakan. Hasil uji korelasi sperman rank diperoleh $\rho$ value sebesar 0,006 < 0,05 ada hubungan peran bidan pada pelaksanaan Inisiasi Menyusu Dini (IMD) Persalinan dengan program IMD pada ibu bersalin di Rumah Sakit Wilayah Kota Pekalongan, nilai rs 0,374 yang berarti hubungannya sedang. Bidan yang mempunyai peran cukup sebaiknya meningkatkan kentrampilan dalam pelaksanaan inisiasi menyusu dini dengan mengikuti pelatihan IMD, melakukan asuhan persalinan sesuai dengan standar operasional seperti Asuhan Persalinan Normal (APN).
\end{abstract}

Kata Kunci: Peran Bidan, Program Inisiasi Menyusu Dini, Ibu Bersalin,

\section{ABSTRACT}

Early initiation of breastfeeding (IMD) and so for the baby. Babies breastfed for 1 hour or more on the mother's chest immediately after birth. Implementation of the IMD on maternal need midwives's role to IMD programs can work as expected. This study aims to determine the relationship of the midwife's role in the implementation of Early Initiation of Breastfeeding (IMD) in the Maternity with Implementatiton Early Initiation of Breastfeeding Program to Maternal in Regional Hospital Pekalongan City. Study used descriptive correlative with cross sectional approach. Samples were midwives in Regional Hospital Pekalongan City as many as 53 peoples. Sampling technique used total sampling. Collecting data used a questionnaire. Results of univariate analysis showed that midwife's role in the implementation Early Initiation of Breastfeeding (IMD) that 31 (58.3\%) was enough and Early Initiation of Breastfeeding (IMD) Program on maternal that 37 (69.8\%) was not implemented. Spearman rank correlation test results showed that there was relationship of the midwife's role to implementation Early Initiation of Breastfeeding (IMD) in the maternity with implementation Early Initiation of Breastfeeding Program to maternal in regional hospital Pekalongan City with $\rho$ value $0.006<0.05$. Correlation spearman rank was 0,374 which means the relationship exactly. For midwives who have sufficient role should increase skill early breastfeeding initiation in the implementation of the IMD and midwife training should undertake delivery care in accordance with the operational standards specified as APN.

Keywords: Midwife's Role, Implementation Early Initiation of Breastfeeding (IMD) Program, Maternity Labor

\section{PENDAHULUAN}

Proses satu jam pertama pasca bayi lahir, melatih bayi untuk secara naluriah menemukan sendiri putting ibunya disebut tindakan inisiasi menyusu dini (IMD). IMD merupakan pilar utama dalam proses menyusui. IMD didefinisikan sebagai proses membiarkan bayi menyusu sendiri setelah kelahiran. Bayi diletakkan di dada ibunya dan bayi itu sendiri dengan segala upayanya mencari puting untuk segera menyusu. Inisiasi menyusu dini sangat penting tidak hanya untuk bayi, namun juga untuk ibu. Bayi disusui selama 1 jam atau lebih di dada ibu sesegera setelah lahir dapat menjaga produktivitas air susu ibu (ASI) karena isapan bayi penting dalam meningkatkan kadar hormon prolaktin yaitu hormon yang merangsang 
kelenjar susu untuk memproduksi ASI (Yuliarti, 2010)

IMD dilakukan pada saat bayi berusia dua hingga 24 jam pertama setelah lahir dapat mencegah $16 \%$ kematian bayi di bawah usia 28 hari. Menunda melakukan IMD dapat meningkatkan risiko kematian pada neonatatus bayi usia 0-18 hari. Bayi yang diberi kesempatan menyusu melalui kontak kulit ke kulit setidaknya selama satu jam, dua kali lebih lama disusui oleh ibunya. IMD akan meningkatkan keberhasilan pemberian ASI esklusif selama 6 bulan. Kemampuan menyesuaikan suhu tubuh dengan suhu yang dibutuhkan bayi meningkat (Aprillia, 2010).

Peran bidan dalam mensosialisasikan inisiasi menyusu dini dapat dilakukan sebelum persalinan dengan cara memberikan informasi kepada ibu hamil pada saat pelaksanaan kelas ibu hamil yaitu pada pertemuan kedua dengan materi tentang persalinan yang meliputi; tandatanda persalinan, tanda bahaya pada persalinan, proses persalinan, inisiasi menyusu dini. (Depkes RI, 2010).

Berdasarkan survei awal pendahuluan terhadap 10 orang ibu bersalin di RS Bendan Kota Pekalongan diketahui bahwa 4 orang $(40 \%)$ menyatakan bahwa peran bidan pada pelaksanaan IMD baik, ibu bersalin menyatakan mendapatkan informasi tentang manfaat dan cara pelaksanaan IMD dari bidan melalui pertemuan kelas ibu hamil. 3 orang (30\%) cukup, ibu bersalin menyatakan mendapatkan informasi tentang IMD dari membaca buku KIA (kesehatan Ibu dan Anak) bukan dari bidan secara langsung dan 3 orang (30\%) cukup, ibu bersalin menyatakan tidak tahu sama sekali tentang IMD. Berdasarkan latar belakang di atas peneliti tertarik untuk melakukan penelitian dengan judul "Hubungan Peran Bidan pada Pelaksanaan Inisiasi Menyusu Dini (IMD) dalam Persalinan dengan Program IMD pada Ibu Bersalin di rumah sakit Kota Pekalongan"

\section{TINJAUAN PUSTAKA \\ Bidan}

Bidan adalah seorang wanita yang telah mengikuti dan menyelesaikan pendidikan yang telah diakui pemerintah dan lulus ujian sesuai dengan persyaratan yang berlaku, dicatat (register), diberi izin secara untuk menjalankan praktek (IBI ,2008). Bidan merupakan profesi yang diakui secara nasional maupun internasional dengan sejumlah praktisi di seluruh dunia.Pengertian bidan dan bidang prakteknya secara internasional telah diakui oleh International Gynekologi and Obstetrisian (FIGO) tahun 1973, WHO dan badan lainnya.Pada tahun 1990 pada pertemuan dewan di Kobe, ICM menyempurnakan definisi tersebut yang kemudian disyahkan oleh FIGO (1991) dan WHO (1992) (Soepardan, 2008).

\section{Peran Bidan}

Peran adalah sebuah harapan budaya terhadap suatu posisi atau kedudukan.Peran ini lebih berkaitan dengan harapan daripada perilaku aktual dan peran itu lebih bersifat normatif daripada deskriptif (Liliweri, 2007).

IBI, (2008) mendeskripsikan peran adalah perangkat tingkah laku yang diharapkan dan dimiliki oleh orang yang berkedudukan dalam masyarakat. Peran yang diharapkan adalah peran sebagai pelaksana, peran, peran sebagai pengelola, peran sebagai pendidik, peran sebagai peneliti.

\section{Inisiasi Menyusu Dini}

Inisiasi menyusu dini merupakan kemampuan bayi mulai menyusu sendiri dengan segera setelah dilahirkan.Cara melakukan IMD ini disebut breast crawl atau merangkak untuk mencari puting ibu secara ilmiah (Siswosuharjo dkk, 2010). Inisiasi Menyusu Dini (IMD) adalah proses membiarkan bayi menyusu sendiri setelah kelahiran. Bayi diletakkan di dada ibunya dan bayi itu dengan segala upayanya mencari puting untuk segera menyusui.Jangka waktunya sesegera mungkin setelah melahirkan (Yuliarti, 2010)

\section{Persalinan}

Persalinan normal adalah proses pengeluaran janin yang terjadi pada kehamilan cukup ulan (37 - 42 minggu) lahir spontan dengan presentasi belakang kepala yang berlangsung dalam 18 jam tanpa komplikasi baik ibu maupun janin (Prawirohardjo, 2006). Persalinan buatan yaitu persalinan dengan tenaga dari luar dengan ekstraksi forceps, ekstraksi vakum dan sectio sesaria. Bila kekuatan yang diperlukan untuk persalinan ditimbulkan dari luar dengan jalan pemberian rangsang disebut sebagai persalinan anjuran. (Rukiyah, Ai yeyeh; dkk, 2009)). Sectio caesarea didefinisikan sebagai kelahiran janin melalui insisi di dinding abdomen (laparotomi) dan dinding uterus (histerotomi) (Cunningham, 2013). 


\section{METODE}

Desain penelitian menggunakan deskriptif korelatif yaitu penelitian untuk menelaah hubungan antara dua variabel pada suatu situasi atau sekelompok objek (Notoatmodjo, 2005). Penelitian ini bertujuan mengetahui hubungan peran bidan pada pelaksanaan Inisiasi Menyusu Dini (IMD) dalam Persalinan dengan program IMD pada ibu bersalin. Pendekatan yang digunakan dalam penelitian adalah cross sectional.

Populasi dalam penelitian ini adalah bidan di semua Rumah Sakit Wilayah Kota Pekalongan sebanyak 58 orang. Sampel adalah bagian dari jumlah dan karakteristik yang dimiliki oleh populasi yang diteliti (Sugiono, 2009). Teknik pengambilan sampel dalam penelitian ini menggunakan total sampling seluruh anggota populasi diambil sebagai sampel penelitian (Hidayat, 2007).

Teknik pengumpulan data dilakukan dengan teknik angket menggunakan kuesioner yaitu pertanyaan tertulis yang diajukan kepada responden. Jawaban diisi oleh responden sesuai dengan daftar isian yang diterima. (Budiarto2002). Teknik angket digunakan untuk memperoleh informasi tentang peran bidan dalam pelaksanaan IMD dalam persalinan.

Teknik angket digunakan untuk memperoleh informasi tentang peran bidan dalam pelaksanaan IMD dalam persalinan. Observasi untuk mengetahui program IMD pada ibu bersalin.

\section{HASIL DAN PEMBAHASAN}

Pada penelitian ini diperoleh hasil dan pembahasan sebagai berikut:

Tabel 1.Distribusi Frekuensi Peran Bidan dalam Pelaksanaan Inisiasi Menyusu Dini di Rumah Sakit Wilayah Kota Pekalongan

\begin{tabular}{|c|c|c|}
\hline $\begin{array}{c}\text { Peran Bidan } \\
\text { dalam } \\
\text { Pelaksanaan } \\
\text { Inisiasi Menyusu } \\
\text { Dini } \\
\end{array}$ & Frekuensi & $\begin{array}{c}\text { Persentase } \\
(\%)\end{array}$ \\
\hline Baik & 14 & 26,4 \\
\hline Cukup & 31 & 58,5 \\
\hline Kurang & 8 & 15,1 \\
\hline Total & 53 & 100 \\
\hline
\end{tabular}

Tabel 1 menunjukkan bahwa 31 orang $(58,3 \%)$ mempunyai peran yang cukup dalam pelaksanaan inisisai menyusui dini 14 orang $(26,4 \%)$ mempunyai peran yang baik dan 8 orang $(15,1 \%)$ mempunyai peran yang kurang.

Tabel 2. Distribusi Frekuensi Program Inisiasi Menyusui Dini pada Ibu Bersalin di Rumah Sakit Wilayah Kota Pekalongan

\begin{tabular}{lcc}
\hline $\begin{array}{c}\text { Program Inisiasi } \\
\text { Menyusu Dini }\end{array}$ & Frekuensi & $\begin{array}{c}\text { Persentase } \\
(\%)\end{array}$ \\
\hline Dilaksanakaan & 16 & 30,2 \\
$\begin{array}{l}\text { Tidak } \\
\text { dilaksanakan }\end{array}$ & 37 & 69,8 \\
\hline \multicolumn{1}{c}{ Total } & 53 & 100 \\
\hline
\end{tabular}

Tabel 2 menunjukkan bahwa 37 orang $(69,8 \%)$ program IMD tidak dilaksanakan dan 16 orang $(30,2 \%)$ program IMD dilaksanakan pada ibu bersalin

Tabel 3. Hubungan Peran Bidan pada Pelaksanaan Inisiasi Menyusu Dini (IMD) dalam Persalinan dengan Program IMD pada Ibu Bersalin di Rumah Sakit Wilayah Kota Pekalongan

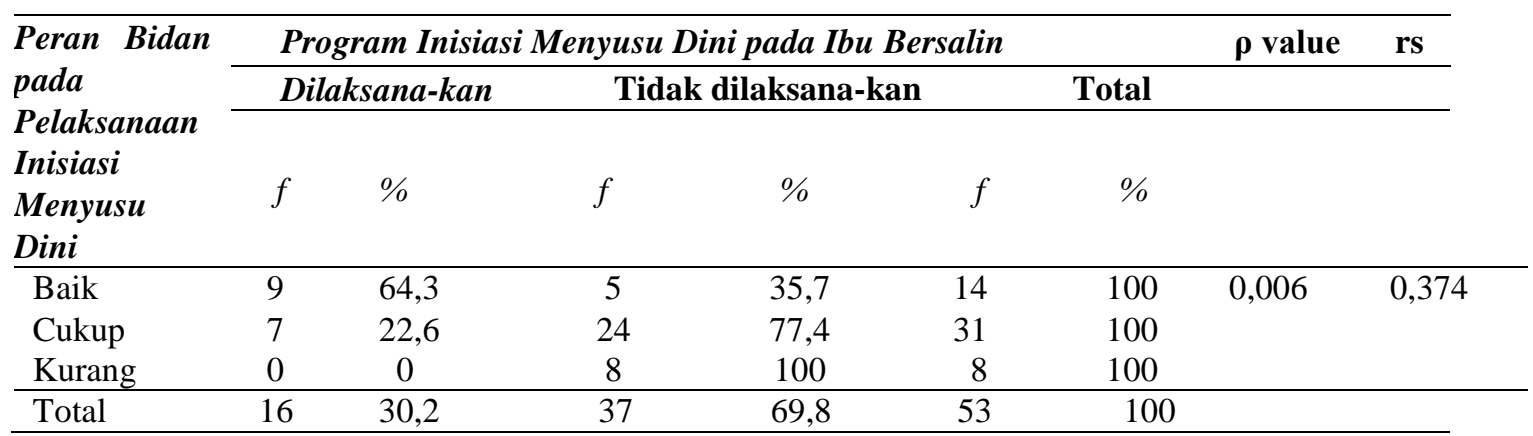


Berdasarkan tabulasi silang di atas, diketahui bahwa dari 31 orang yang mempunyai peran cukup pada pelaksanaan IMD terdapat 24 orang $(77,4 \%)$ yang tidak melaksanakan program IMD pada ibu bersalin dan 7 orang $(22,6 \%)$ melaksanakan program IMD pada ibu bersalin. Dari 14 orang yang mempunyai peran baik pada pelaksanaan inisiasi menyusu dini terdapat 9 orang $(64,3 \%)$ melaksanakan program IMD dan 5 orang $(35,7 \%)$ tidak melaksanakan. Dan ada 8 orang (100\%) tidak melaksanakan program IMD. Dari hasil uji korelasi spearman diperoleh $\rho$ value sebesar $0,006<0,05$, maka $H_{\alpha}$ diterima, berarti ada hubungan peran bidan pada pelaksanaan Inisiasi Menyusu Dini (IMD) dalam Persalinan dengan program IMD pada ibu bersalin di Rumah Sakit Wilayah Kota Pekalongan. Nilai $r_{s}$ sebesar 0,374, hal ini menunjukkan kekuatan hubungan sedang. Hasil penelitian ini menghasilkan nilai $r_{s}$ yang positif sehingga dapat diartikan bahwa semakin baik peran bidan dalam pelaksanaan program IMD maka semakin baik pula program IMD pada ibu bersalin.

1. Peran Bidan dalam Pelaksanaan Inisiasi Menyusu Dini

Hasil penelitian menunjukkan bahwa bahwa 31 orang $(58,3 \%)$ mempunyai peran yang cukup dalam pelaksanan inisiasi menyusu dini, 14 orang $(26,4 \%)$ mempunyai peran yang baik dan 8 orang $(15,1 \%)$ mempunyai peran yang kurang.

Pengetahuan bidan yang cukup disebabkan bidan kurang memahami peran sebagai pelaksana, salah satunya merencanakan asuhan kebidanan pada bayi baru lahir dengan melaksanakan program IMD. Berdasarkan hasil penelitian diketahui bahwa 43 orang $(81,1 \%)$ menyatakan merencanakan dengan ibu bersalin untuk melakukan IMD. Hal ini sesuai dengan pendapat (IBI, 2008) yang menyatakan salah satu peran bidan sebagai pelaksana adalah mampu melakukan tugas mandiri primer yaitu memberikan asuhan kebidanan kepada klien dalam masa persalinan dengan melibatkan klien atau keluarga dan memberikan asuhan kebidanan pada bayi baru lahir.

Peran bidan yang baik disebabkan bidan memahami tugas mandiri, kolaborasi dan ketergantungan dalam menjalankan peran sebagai pelaksana. Pemahaman terhadap peran yang baik dapat menciptakan peran yang baik bidan pada ibu bersalin, khususnya pelaksanaan IMD. Peran yang baik terutama dalam hal memberikan informasi tentang IMD. Hasil penelitian menunjukkan bahwa 50 orang $(94,3 \%)$ menyatakan bahwa bidan memberikan informasi tentang IMD pada ibu bersalin. Hal ini sesuai dengan pendapat (IBI 2008,) yang menyatakan sebagai pelaksana bidan memiliki tiga kategori tugas yaitu tugas mandiri, tugas kolaborasi dan tugas ketergantungan.

Peran bidan yang kurang disebabkan bidan kurang mendapatkan pelatihan tentang IMD dan tidak berinisiatif untuk meminta pelatihan tentang IMD pada pihak rumah sakit. Hal ini dapat dilihat dari distribusi frekuensi diketahui bahwa 35 orang (66\%) tidak meminta pelatihan IMD pada pihak rumah sakit.

Bidan yang mempunyai peran yang cukup dan kurang sebaiknya meningkatkan ketrampilan dalam pelaksanaan IMD sehingga dapat melaksanakan IMD pada ibu bersalin dengan baik. Peran bidan sebagai pengelola dibutuhkan untuk meningkatkan pelaksanaan IMD di rumah sakit. Dari distribusi frekuensi diketahui bahwa 15 orang $(28,3 \%)$ tidak menjadikan program IMD sebagai salah satu standar dalam memberikan asuhan persalinan di rumah sakit , 31 orang $(58,5 \%)$ tidak menegur bidan lain yang tidak melakukan IMD pada ibu bersalin dan 24 orang (45,3\%) tidak membuat laporan tertulis pelaksanaan IMD.

Hasil penelitian Husna (2014) yang menyatakan bahwa bidan yang memberikan peran tinggi terhadap responden sebesar $65 \%$ dan berperan rendah $35 \%$, dan terdapat hubungan antara peran bidan dengan program IMD.

2. Program Inisiasi Menyusu Dini pada Ibu Bersalin

Hasil penelitian menunjukkan bahwa 37 orang $(69,8 \%)$ program IMD tidak dilaksanakan dan 16 orang $(30,2 \%)$ program IMD dilaksanakan pada ibu bersalin.

Inisiasi menyusu dini merupakan kemampuan bayi mulai menyusu sendiri dengan segera setelah dilahirkan. Cara melakukan IMD ini disebut breast crawl atau merangkak untuk mencari puting ibu secara ilmiah (Siswosuharjo dkk, 2010).

Program IMD yang tidak dilaksanakan disebabkan banyak faktor. Salah satunya kurangnya konseling oleh tenaga kesehatan tentang inisiasi menyusu dini saat kehamilan dan persiapan persalinan. Ibu dan keluarga kurang memahami program IMD, sehingga dibutuhkan peran petugas kesehatan khususnya bidan untuk memberikan konseling tentang manfaat dan pelaksanaan IMD pada ibu saat persalinan. Hal ini sesuai dengan United Nations International Children's Emergency Fund (UNICEF) 
dalam (Luba, 2019). Ada banyak sekali masalah yang dapat menghambat inisiasi menyusu dini, salah satunya kurangnya konseling oleh tenaga kesehatan tentang praktik inisiasi menyusu dini (Aprilia, 2010).

Peran bidan yang baik dalam pelaksanaan IMD dapat mensukseskan program IMD di rumah sakit. Program IMD merupakan program yang dirancang untuk mengurangi angka kematian ibu dan bayi. Hal ini sesuai dengan penelitian Husna (2014) yang menyatakan bahwa terdapat hubungan antara peran bidan dengan program IMD.

Program IMD yang tidak dilaksanakan terutama pada persalinan caesar karena membutuhkan waktu yang lebih lama sehingga dibutukan kesabaran bidan untuk membimbing ibu dan bayinya dalam melakukan IMD. Hal ini dapat diketahui dari distribusi frekuensi yang menyatakan bahwa 29 orang $(54,7 \%)$ tidak memberikan kesempatan kontak kulit dengan kulit pada ibu yang melahirkan dengan tindakan seperti operasi caesar. Program IMD sebenarnya dapat dilakukan baik pada persalinan normal maupun persalinan caesar. Menurut Aprilia (2010), pada persalinan melalui operasi, inisiasi menyusu dini butuh waktu hingga lebih dari satu jam dengan tingkat keberhasilan 50\%.

Program IMD yang dilaksanakan disebabkan bidan sudah memahami tentang keuntungan program IMD bagi peningkatan derajat kesehatan ibu dan anak seperti mengurangi angka kematian ibu dan bayi baru lahir, serta meningkatkan derajat kesehatan di kemudian hari sebagai implikasi pemberian kolostrum sejak dini yang berfungsi sebagai kekebalan tubuh.

Pelaksanaan program IMD yang baik membutuhkan dukungan kebijakan dari pemerintah dan mensosialisasikan program IMD baik pada masyarakat maupun pada bidan sehingga masyarakat dan bidan memperoleh informasi dan terbentuk persepsi yang baik terhadap program IMD. Pelaksanaan program IMD yang baik yaitu terdapat 34 orang $(64,2 \%)$ menengkurapkan bayi di dada dan perut ibu. Membiarkan kulit bayi melekat dengan kulit ibu dan mempertahankan posisi kontak tersebut minimum satu jam atau setelah menyusu awal selesai. Keduanya diselimuti, jika perlu gunakan topi bayi.

Hal ini dapat meningkatkan pelaksanaan program IMD pada ibu bersalin. Hasil penelitian Aprilia (2010) menyebutkan bahwa kebijakan berhubungan dengan sosialisasi program IMD pada bidan.

3. Hubungan Peran Bidan pada Pelaksanaan Inisiasi Menyusu Dini (IMD) dalam Persalinan dengan Program IMD pada Ibu Bersalin di Rumah Sakit Wilayah Kota Pekalongan

Hasil penelitian dengan analisa korelasi spearman diperoleh $\rho$ value sebesar $0,006<0,05$, maka $\mathrm{H}_{0}$ ditolak, berarti ada peran bidan pada pelaksanaan Inisiasi Menyusu Dini (IMD) dalam Persalinan dengan program IMD pada ibu bersalin di Rumah Sakit Wilayah Kota Pekalongan. Nilai $r_{s}$ sebesar 0,374 , hal ini menunjukkan kekuatan hubungan sedang.

Peran merupakan seperangkat perilaku dari orang yang memiliki posisi dalam sistem sosial. Peran perawat dapat ditentukan jika perawat berinteraksi dengan satu atau lebih orang dalam situasi keperawatan (Asmadi, 2008).

Peran bidan dalam pelaksanaan IMD merupakan sebuah tugas dan tanggung jawab yang diperoleh bidan dalam masyarakat, karena posisi bidan sebagai tenaga kesehatan yang bertanggung jawab membantu masyarakat dalam kehamilan dan persalinan. Peran yang dimilliki bidan telah diatur oleh pemerintah, salah satunya peran dalam melaksanakan inisiasi menyusu dini. Pemahaman yang baik oleh bidan terhadap peran yang dimiliki dalam asuhan kebidanan persalinan dan bayi baru lahir, mengakibatkan bidan melaksanakan program IMD pada ibu bersalin.

Peran bidan yang baik dalam pelaksanaan IMD dapat mensukseskan program IMD di rumah sakit. Program IMD merupakan program yang dirancang untuk mengurangi angka kematian ibu dan bayi. Hal ini sesuai dengan penelitian Husna (2014) yang menyatakan bahwa terdapat hubungan antara peran bidan dengan program IMD.

Pelaksanaan program IMD di rumah sakit mengalami peningkatan sejak dimunculkan Peraturan Pemerintah No. 33 Tahun 2012 tentang Air Susu Ibu karena program pelaksanaan IMD merupakan suatu kewajiban yang harus dilaksanakan oleh seorang bidan sebagai tenaga kesehatan.. Peran bidan tersebut tertutang dalam pasal 9 ayat (1) yang menyebutkan bahwa tenaga kesehatan dan penyelenggara fasilitas pelayanan kesehatan wajib melakukan inisiasi menyusu dini terhadap Bayi yang baru lahir kepada ibunya paling singkat selama 1 (satu) jam. 
Peran bidan dapat dibangun dengan komunikasi yang baik antara bidan dengan ibu bersalin sehingga ibu bersedia melakukan IMD dan bidan dapat melaksanakan program IMD dengan baik. Hal ini sesuai dengan penelitian Fazri (2012) yang menyatakan bahwa ada pengaruh antara keterbukaan, sikap dan kesetaraan dalam komunikasi terapeutik dengan pelaksanaan IMD.

Pihak rumah sakit perlu mendukung pelaksanaan program IMD dengan memberikan rawat gabung ibu dan bayi. Berdasarkan hasil penelitian diketahui bahwa $100 \%$ rumah sakit sudah melakukan rawat gabung ibu bersalin dan bayi. Hal ini disebabkan adanya Peraturan Pemerintah No. 33 Tahun 2012 pasal 9 ayat (2) yang menyebutkan bahwa tenaga Kesehatan dan penyelenggara fasilitas pelayanan kesehatan wajib menempatkan ibu dan bayi dalam 1 (satu) ruangan atau rawat gabung kecuali atas indikasi medis yang ditetapkan oleh dokter.

Dalam upaya pelaksanaan program IMD maka pihak rumah sakit perlu melakukan evaluasi terhadap kinerja dalam pelaksanaan IMD dan memberikan sanksi pada bidan yang tidak menjalankan perannya dalam pelaksaan IMD dengan baik. Pihak rumah sakit juga perlu memberikan pelatihan tentang pelaksaan IMD pada bidan sehingga bidan lebih terampil dan percaya diri dalam melaksanakan IMD pada ibu bersalin. Hal ini sesuai dengan Yuliarti (2010) yang menyatakan bahwa pihak rumah sakit juga harus memberikan pelatihan pada petugasnya dalam pelaksanaan IMD.

\section{KESIMPULAN}

Peran bidan dalam pelaksanaan inisiasi menyusu dini diketahui sebagian besar mempunyai peran yang cukup dalam pelaksanaan IMD yaitu sebanyak 31 (58,5\%). Program inisiasi menyusu dini sebagian besar tidak dilaksanakan yaitu sebanyak 37 (69,8\%). Ada hubungan peran bidan pada pelaksanaan Inisiasi Menyusu Dini (IMD) dalam Persalinan dengan program IMD pada ibu bersalin di Rumah Sakit Wilayah Kota Pekalongan dengan $\rho$ value sebesar $0,006<0,05$ dan nilai rs sebesar 0,374 sehingga kekuatan antara peran dengan pelaksanaan inisiasi menyusu dini dalam persalinan dengan program IMD pada ibu bersalin di rumah sakit wilayah kota Pekalonan adalah sedang.

\section{SARAN}

Bidan sebaiknya memahami peran sebagai pelaksana dalam program IMD, sehingga pelaksanaan program IMD di rumah sakit dapat dilaksanakan dengan baik dan sesuai dengan program IMD. Bidan sebaiknya meningkatkan ketrampilan dalam pelaksanaan IMD sehingga dapat melaksanakan IMD pada ibu bersalin dengan baik. Program IMD yang tidak dilaksanakan terutama pada persalinan caesar, maka pihak rumah sakit sebaiknya meningkatkan pelatihan tentang IMD kepada bidan sehingga dapat melaksanakan program IMD terutama pada persalinan caesar dengan baik. Pihak rumah sakit sebaiknya menerapkan Standar Operasional Prosedur (SOP) persalinan dengan inisiasi menyusu dini dan mensosialisasikan kepada seluruh bidan dan melakukan evaluasi terhadap pelaksanaan SOP tersebut secara berkala.

\section{DAFTAR PUSTAKA}

Asmadi. 2008, Teknik Prosedural Konsep \& Aplikasi Kebutuhan Dasar Klien. Jakarta: Salemba Medika

Aprilia, Yesie. 2010, Hipnostetri: Rileks Nyaman dan Aman Saat Hamil dan Melahirkan. Jakarta: Gagas Media

Budiarto. 2002, Biostatistik untuk Kedokteran dan Kesehatan Masyarakat. Jakarta: EGC

Cunningham. 2013. Obstetri Williams. Jakarta: EGC

Depkes. 2010, Riset Kesehatan Dasar. www.depkes.go.id

Fazri. 2012. Pengaruh Komunikasi Terapeutik Terhadap Pelaksanaan Inisiasi Menyusui Dini Pada Ibu Nifas di RSUD Tengku Mansyur Kota Tanjungbalai http://repository.usu.ac.id/handle/123456789 $\underline{133921}$

Hidayat. 2007. Riset Keperawatan dan Teknik Penulisan Ilmiah. Jakarta: Salemba Medika

Husna. 2014. Hubungan Dukungan Suami Dan Peran Bidan Dengan Pelaksanaan IMD, https://digilib.uns.ac.id/dokumen/detail/3802 5/Hubungan-Dukungan-Suami-Dan-PeranBidan-Dengan-Pelaksanaan-InisiasiMenyusu-Dini

IBI. 2008. 50 Tahun IBI: Bidan Menyongsong Masa Depan. Jakarta: Pengurus Pusat IBI

Liliweri. 2007. Makna Budaya dalam Komunikasi antar Budaya. Yogyakarta: LkiS 
Luba, 2019. Gambaran Pelaksanaan Inisiasi Menyusui Dini di RS Ibu dan Anak Pertiwi Makassar,

https://media.neliti.com/media/publications/ 286101-gambaran-pelaksanaan-inisiasimenyusu-di-f0685824.pdf

Notoatmodjo. 2005. Metodologi Penelitian Kesehatan. Jakarta: Rineka Cipta,

Prawirohardjo, S. 2006. Ilmu Kebidanan. Jakarta: Yayaysan Bina Pustaka,

Rukiyah, Ali Yeyeh, dkk, 2009. Asuhan Kebidanan II Persalinan. Jakarta : CV. Trans Info Media.

Siswosuharjo dkk, 2010. Panduan Super Lengkap Hamil Sehat. Jakarta: Penebar Plus

Soepardan. 2008. Konsep Kebidanan. Jakarta: EGC

Sugiono. 2009. Metode Penelitian Kuantitatif, Kualitatif, R \& D. Bandung: Alfabeta,

Yuliarti. 2010. Keajaiban ASI: Makanan Terbaik untuk Kesehatan, Kecerdasan, dan Kelincahan Si Kecil. Jakarta: Andi Offset 